\title{
QUALITY OF LIFE IN WOMEN AFTER MASTECTOMY. CLINICAL AND SOCIAL STUDY
}

DOI: 10.36740/WLek202103109

\author{
Włodzisław Kuliński ${ }^{1,2}$, Michał Kosno ${ }^{1}$ \\ ${ }^{1}$ COLLEGIUM MEDICUM, JAN KOCHANOWSKI UNIVERSITY, KIELCE, POLAND \\ 2DEPARTMENT OF REHABILITATION, MILITARY INSTITUTE OF MEDICINE, WARSAW, POLAND
}

\begin{abstract}
The aim: To assess the quality of life in women after mastectomy.

Materials and methods: The study included 25 women after mastectomy. The patients were aged 31 to over 50 years and were members of a breast cancer support group at the Holy Cross Cancer Centre in Kielce. During group meetings, the patients underwent rehabilitation and worked with psychologists and social workers.

Results: Most women after mastectomy who underwent breast reconstruction or wore breast prostheses reported a better quality of life. Mastectomy affects ipsilateral upper limb function and causes difficulty with activities of daily living, such as cleaning, cooking, brushing hair, bathing, and dressing.

Conclusions: 1 . All women who rated their health as poor experienced such negative emotions as sadness, low mood, dejection. 2. Mastectomy affects ipsilateral upper limb function. 3. Breast reconstruction after mastectomy improves patient-rated quality of life. 4. Pain in the ipsilateral upper limb is considerably more common in women with a limited range of motion. 5. All women who participated in breast cancer support group meetings found support there and the time they spent together resulted in an improved quality of life.
\end{abstract}

KEY WORDS: mastectomy, clinical problems, quality of life

Wiad Lek. 2021;74(3 p.l):429-435

\section{INTRODUCTION}

Breast cancer is one of the most important epidemiological problems and the second most common malignancy in women worldwide. In Poland, the risk of developing a malignant breast tumour is high, with 18,000 to 19,000 new cases and 6,000 deaths per year. The incidence rate has been steadily increasing and the mortality rate rose by $7.2 \%$ in 2019. Breast cancer usually affects women over the age of 50 years, but $33 \%$ of cases are reported in patients aged 30 to 49 years. In the recent years, the incidence of breast cancer in young women has increased two-fold [1-6].

\section{RISK FACTORS}

The most important risk factors for breast cancer include age, gender, a family history of breast cancer, diagnosed intraductal hyperplasia, genetic factors, hormonal factors, ionising radiation, and long-term use of hormone replacement therapy and hormonal contraception [4-6].

The recent years have seen dynamic developments in the treatment of breast cancer. Currently, patients are managed with combination therapy that includes surgery, radiotherapy, and systemic methods, i.e. chemotherapy and hormone therapy. Treatment can be divided into less invasive surgical procedures (breast-conserving surgery), removal of the whole breast (mastectomy), and adjuvant treatment (radiotherapy, chemotherapy, hormone therapy) [1-3].
Mastectomy is associated with negative consequences that considerably limit ipsilateral upper limb function and cause postural changes and lymphoedema. Lymphoedema develops in the upper limb due to impaired lymph drainage after axillary lymph node removal. Axillary web syndrome, or cording, manifests as pain in the axillary fossa and results from the disruption of superficial veins and lymphatic vessels in this region [6-8].

Treatment of patients after radical breast cancer surgery should always include comprehensive in-hospital and out-patient rehabilitation; patients will also benefit from participating in breast cancer support group meetings and activities.

\section{QUALITY OF LIFE IN WOMEN AFTER MASTECTOMY}

\section{SOCIAL, PSYCHOLOGICAL, AND EMOTIONAL CONSEQUENCES OF MASTECTOMY}

Consequences of breast cancer include not only functional, physical impairment, but also psychological and social issues. Cancer can suddenly change one's entire life. In most cases, a breast cancer diagnosis is associated with negative emotions, for example anxiety, fear, the feeling of being in danger, irritability, hypersensitivity, anger, and sometimes depression. This has a significant effect on patients' ability 
Table 1. Age of study patients

\begin{tabular}{ccc}
\hline & $\mathbf{N}$ & [\%] \\
\hline 31-40 years & 2 & 8.0 \\
\hline 41-50 years & 8 & 32.0 \\
\hline Over 50 years & 15 & 60.0 \\
\hline Total & 25 & 100.0 \\
\hline
\end{tabular}

Table 2. Patient-rated health

\begin{tabular}{ccc}
\hline & $\mathbf{N}$ & {$[\%]$} \\
\hline Very good & 3 & 12.0 \\
\hline Good & 13 & 52.0 \\
\hline Fair & 8 & 32.0 \\
\hline Poor & 1 & 4.0 \\
\hline Total & 25 & 100.0 \\
\hline
\end{tabular}

Table 3. Reaction of study patients to cancer diagnosis.

\begin{tabular}{ccc}
\hline & $\mathbf{N}$ & [\%] \\
\hline Shock, it is difficult to believe & 12 & 48.0 \\
\hline $\begin{array}{c}\text { I want to start treatment as } \\
\text { soon as possible }\end{array}$ & 13 & 52.0 \\
\hline Total & 25 & 100.0 \\
\hline
\end{tabular}

Table 4. Time from surgery.

\begin{tabular}{ccc}
\hline & N & [\%] \\
\hline Less than a year & 3 & 12.0 \\
\hline 1-5 years & 9 & 36.0 \\
\hline 6-10 years & 8 & 32.0 \\
\hline More than 10 years & 5 & 20.0 \\
\hline Total & 25 & 100.0
\end{tabular}

Table 5. Difficulty dressing.

\begin{tabular}{ccc}
\hline & N & [\%] \\
\hline No difficulty & 6 & 24.0 \\
\hline Slight difficulty & 4 & 16.0 \\
\hline Moderate difficulty & 10 & 40.0 \\
\hline Considerable difficulty & 5 & 20.0 \\
\hline Total & 25 & 100.0 \\
\hline
\end{tabular}

to accept the diagnosis and adjust to the new, changed life situation; in addition, it may affect the process of physical and mental recovery. Consequently, acceptance and self-assessment are very important in cancer treatment, which is usually complex and relatively long-term. Breast cancer patients worry about how they will respond to treatment and are afraid of recurrence or death. As a result, they may feel helpless, sad, and anxious about their changing life situation. It is important to assess whether they will be able to cope with the limitations associated with their disease and remain independent in their everyday life [7-16].
Table 6. Ipsilateral limb pain.

\begin{tabular}{ccc}
\hline & $\mathbf{N}$ & [\%] \\
\hline Yes, I experience pain & 8 & 32.0 \\
\hline I do not experience pain & 12 & 48.0 \\
\hline I have occasional pain & 5 & 20.0 \\
\hline Total & 25 & 100.0 \\
\hline
\end{tabular}

Table 7. Limited range of motion after surgery.

\begin{tabular}{ccc}
\hline & $\mathbf{N}$ & {$[\%]$} \\
\hline Yes, I have a limited range of motion & 7 & 28.0 \\
\hline I do not have a limited range of motion & 16 & 64.0 \\
\hline I have a slightly limited range of motion & 2 & 8.0 \\
\hline Total & 25 & 100.0 \\
\hline
\end{tabular}

Table 8. Change in the way patients cared about their appearance as a result of mastectomy.

\begin{tabular}{ccc}
\hline & $\mathbf{N}$ & [\%] \\
\hline Yes & 11 & 44.0 \\
\hline No & 14 & 56.0 \\
\hline Total & 25 & 100.0 \\
\hline
\end{tabular}

Table 9. Breast reconstruction after mastectomy.

\begin{tabular}{ccc}
\hline & $\mathbf{N}$ & {$[\%]$} \\
\hline Yes & 6 & 24.0 \\
\hline No & 19 & 76.0 \\
\hline Total & 25 & 100.0
\end{tabular}

Table 10. Patient-rated influence of breast reconstruction on everyday life.

\begin{tabular}{ccc} 
& N & {$[\%]$} \\
\hline Significant influence & 4 & 66.7 \\
\hline Moderate influence & 2 & 33.3 \\
\hline Total & 6 & 100.0 \\
\hline
\end{tabular}

Table 11. Frequency of rehabilitation.

\begin{tabular}{ccc}
\hline & $\mathbf{N}$ & {$[\%]$} \\
\hline Once a week & 4 & 16.0 \\
\hline 2-3 times a week & 12 & 48.0 \\
\hline 4 or more & 9 & 36.0 \\
\hline Total & 25 & 100.0
\end{tabular}

Moreover, breast cancer patients have to not only accept themselves in a new situation and come to terms with their disease, but also find their place among family members and friends. Mastectomy leaves both physical and mental scars and may result in such problems as the so-called half-woman complex, where women feel 'defective', unable to accept their body, anxious about no longer being sexually attractive, and worried their partner might leave them. Social interactions and support from family and friends influence recovery and prolong patients' lives [17-20]. 
Table 12. Effects of rehabilitation on everyday functioning.

\begin{tabular}{ccc}
\hline & $\mathbf{N}$ & [\%] \\
\hline Yes & 23 & 92.0 \\
\hline No & 2 & 8.0 \\
\hline Total & 25 & 100.0 \\
\hline
\end{tabular}

Table 13. Wearing a breast prosthesis.

\begin{tabular}{ccc}
\hline & $\mathbf{N}$ & [\%] \\
\hline Yes & 16 & 64.0 \\
\hline No & 9 & 36.0 \\
\hline Total & 25 & 100.0 \\
\hline
\end{tabular}

Table 14. Difficulty carrying groceries

\begin{tabular}{ccc}
\hline & N & [\%] \\
\hline Slight & 10 & 40.0 \\
\hline Fairly considerable & 4 & 16.0 \\
\hline Considerable & 11 & 44.0 \\
\hline Total & 25 & 100.0
\end{tabular}

Table 15. Difficulty cleaning the house

\begin{tabular}{ccc}
\hline & N & [\%] \\
\hline Slight & 11 & 44.0 \\
\hline Fairly considerable & 7 & 28.0 \\
\hline Considerable & 7 & 28.0 \\
\hline Total & 25 & 100.0 \\
\hline
\end{tabular}

\section{THE AIM}

The aim of the present study was to assess the quality of life in women after mastectomy.

\section{MATERIALS AND METHODS}

\section{PROBLEMS AND HYPOTHESES}

The main research problem addressed in the study can be expressed as follows: does rehabilitation have a positive effect on the quality of life in women after mastectomy?

The following hypotheses were formulated and then verified:

1. Limb pain occurred more often in women who had a limited range of motion after surgery and were aged over 50 years.

2. Women after mastectomy rarely experience such emotions as sadness, low mood, anxiety, and dejection, which is associated with their relationship with family members.

3. Most women found support and understanding in a breast cancer support group and believe that their participation in group meetings improved their quality of life.

\section{RESEARCH METHODS}

The data collected from study patients were systematically entered into an Excel database created for the study. All calculations were performed with the SPSS Statistics 21.0.
Table 16. Meetings with a psychologist.

\begin{tabular}{ccc}
\hline & $\mathbf{N}$ & [\%] \\
\hline Yes & 18 & 72.0 \\
\hline No & 7 & 28.0 \\
\hline Total & 25 & 100.0 \\
\hline
\end{tabular}

Table 17. Negative emotions.

\begin{tabular}{ccc}
\hline & N & [\%] \\
\hline Often & 5 & 20.0 \\
\hline Rarely & 8 & 32.0 \\
\hline Very rarely & 12 & 48.0 \\
\hline Total & 25 & 100.0 \\
\hline
\end{tabular}

Table 18. Acceptance of physical appearance.

\begin{tabular}{ccc}
\hline & N & [\%] \\
\hline I do not accept it & 1 & 4.0 \\
\hline I somewhat accept it; I am no longer attractive & 2 & 8.0 \\
\hline I moderately accept it; I got used to it & 4 & 16.0 \\
\hline I mostly accept it & 9 & 36.0 \\
\hline I fully accept it & 9 & 36.0 \\
\hline Total & 25 & 100.0
\end{tabular}

Table 19. Participation in breast cancer support group meetings and improvements in the quality of life

\begin{tabular}{ccc}
\hline & N & [\%] \\
\hline Yes, it improved my quality of life & 25 & 100.0 \\
\hline
\end{tabular}

software. Participation in the study was voluntary. The study data were used to perform descriptive, graphical, and statistical analyses. The statistical relationship between the characteristics analysed in the study was tested with a chi-squared test.

The study included 25 women who were members of a breast cancer support group (Amazon Club) at the Holy Cross Cancer Centre in Kielce. The follow-up period was 5 months. The women participated in rehabilitation and met with psychologists and social workers.

Most study patients were aged either over 50 years $(60 \%)$ or between 41 and 50 years (32\%). Only two women underwent mastectomy before the age of 40 years (Table1).

Most study patients lived in a city with over 100,000 inhabitants (52\%); others lived in rural areas (28\%), a town with 10,000 to 100,000 inhabitants $(12 \%)$ or a town with up to 10,000 inhabitants (8\%).

Most study patients were married.

$48 \%$ of study patients had higher education, $40 \%$ had secondary education, and $12 \%$ had vocational secondary education.

Most study patients rated their current health as good $(52 \%)$ or fair (32\%) (Table 2).

Usually, patients wanted to start cancer treatment as soon as possible (52\%); others (48\%) were deeply shocked and could not believe that they were affected by breast cancer (Table 3). 
Table 20. Fisher's test for correlation between pain and surgery.

\begin{tabular}{|c|c|c|c|c|c|c|}
\hline & & & \multicolumn{3}{|c|}{$\begin{array}{l}\text { Do you have a limited range of motion in your arm on the } \\
\text { operated side after surgery? }\end{array}$} & \multirow[b]{2}{*}{ Test result } \\
\hline & & & $\begin{array}{c}\text { yes, I have a } \\
\text { limited range of } \\
\text { motion }\end{array}$ & $\begin{array}{l}\text { I do not have a } \\
\text { limited range of } \\
\text { motion }\end{array}$ & $\begin{array}{l}\text { I have a slightly } \\
\text { limited range of } \\
\text { motion }\end{array}$ & \\
\hline \multirow{6}{*}{$\begin{array}{l}\text { Do you } \\
\text { experience pain in } \\
\text { your arm on the } \\
\text { operated side? }\end{array}$} & \multirow{2}{*}{$\begin{array}{l}\text { yes, I experience } \\
\text { pain }\end{array}$} & $\mathrm{N}$ & 6 & 2 & 0 & \multirow{8}{*}{$p=0.001$} \\
\hline & & [\%] & 85.7 & 12.5 & 0.0 & \\
\hline & \multirow{2}{*}{$\begin{array}{l}\text { I do not experience } \\
\text { pain }\end{array}$} & $\mathrm{N}$ & 0 & 11 & 1 & \\
\hline & & [\%] & 0.0 & 68.8 & 50.0 & \\
\hline & \multirow{2}{*}{$\begin{array}{l}\text { I have occasional } \\
\text { pain }\end{array}$} & $\mathrm{N}$ & 1 & 3 & 1 & \\
\hline & & [\%] & 14.3 & 18.8 & 50.0 & \\
\hline \multirow{2}{*}{\multicolumn{2}{|c|}{ Total }} & $\mathrm{N}$ & 7 & 16 & 2 & \\
\hline & & [\%] & 100.0 & 100.0 & 100.0 & \\
\hline
\end{tabular}

$\mathrm{p}$ - significance; $\chi_{2} 2$-test statistic; $d f$ - degrees of freedom

Table 21. Acceptance of physical appearance.

\begin{tabular}{ccc}
\hline \multicolumn{3}{c}{ Do you accept your physical appearance? } \\
\hline & $\mathbf{N}$ & [\%] \\
\hline I do not accept it & 1 & 4.0 \\
\hline I somewhat accept it; I am no longer attractive & 2 & 8.0 \\
\hline I moderately accept it; I got used to it & 4 & 16.0 \\
\hline I mostly accept it & 9 & 36.0 \\
\hline I fully accept it & 9 & 36.0 \\
\hline Total & 25 & 100.0 \\
\hline
\end{tabular}

Most study patients underwent breast cancer surgery either between 1 and 5 years before the study (36\%) or between 6 and 10 years before the study (32\%); in five women $(20 \%)$, the surgical procedure had been performed more than 10 years before they entered the study (Table 4$)$. Most study patients (60\%) had no difficulty eating meals. Four women (16\%) had slight difficulty with this activity, three patients (12\%) had moderate difficulty, and another three (12\%) had considerable difficulty eating meals.

A large group of study patients admitted they had moderate difficulty bathing (40\%). One patient (4\%) had very considerable difficulty; four patients (16\%) complained of considerable difficulty and three women $(12 \%)$ had slight difficulty with this task.

Most study patients had moderate difficulty (40\%) dressing and five women (20\%) had considerable difficulty with this task (Table 5).

Most study patients either did not have any difficulty walking up the stairs (44\%) or experienced slight difficulty with this activity (36\%). Two women complained of considerable difficulty walking up the stairs.

Most study patients had difficulty carrying groceries.

The majority of study patients either did not have difficulty walking longer distances (44\%) or had slight difficulty with this activity (36\%).

The majority of study patients responded that they experienced frequent $(32 \%)$ or occasional $(20 \%)$ pain in their ipsilateral upper limb (Table 6).
Seven women (28\%) declared they had a limited range of motion. Two study patients (8\%) described their range of motion as slightly limited (Table 7).

The majority of study patients worried about possible health problems after mastectomy (40\%) and about decreased physical fitness (36\%). Some patients were also anxious that their partners might not accept them (24\%).

Only one study patient (4\%) underwent bilateral mastectomy.

A vast majority of study patients declared that the way they cared about their physical appearance did not change after mastectomy (56\%) (Table 8).

Most study patients did not undergo breast reconstruction after mastectomy (76\%). The majority of patients who did receive breast reconstruction underwent this procedure a year after mastectomy (83.3\%) (Table 9)

The majority of study patients (66.7\%) after breast reconstruction believed that the procedure had a significant influence on their everyday life (Table 10)

The majority of study patients underwent physical therapy either 2 to 3 times a week (48\%) or 4 or more times a week (36\%) (Table 11). A vast majority of patients declared that they performed self-massage of the ipsilateral upper limb every day.

The majority of the women assessed in the study believed that rehabilitation had a positive effect on their everyday functioning (92\%) (Table 12)

Most study patients declared that they had and used a breast prosthesis (Table 13)

A large group of study patients (48\%) accepted their breast prosthesis and felt good wearing it. Four women (16\%) were unable to accept their breast prosthesis.

The majority of study patients believed that their breast prosthesis had an effect on their quality of life and visibly improved it (52\%).

Most patients had slight difficulty brushing their hair (52\%). However, many patients (44\%) had fairly considerable difficulty with this activity and one patient $(4 \%)$ had very considerable difficulty.

One patient had considerable difficulty dressing; the other patients had either slight difficulty (48\%) or fairly considerable difficulty (48\%) with this task. 
Table 22. Fisher's test for assessment of health vs. negative emotions.

\begin{tabular}{|c|c|c|c|c|c|c|c|}
\hline & & & \multicolumn{4}{|c|}{ How would you rate your current health? } & \multirow{2}{*}{ Test result } \\
\hline & & & very good & good & fair & poor & \\
\hline \multirow{6}{*}{$\begin{array}{l}\text { How often do you } \\
\text { experience such emotions } \\
\text { as sadness, low mood, } \\
\text { dejection? }\end{array}$} & \multirow{2}{*}{ Often } & $\mathrm{N}$ & 0 & 1 & 3 & 1 & \multirow{8}{*}{$p=0.002$} \\
\hline & & [\%] & 0.0 & 7.7 & 37.5 & 100.0 & \\
\hline & \multirow{2}{*}{ Rarely } & $\mathrm{N}$ & 0 & 3 & 5 & 0 & \\
\hline & & [\%] & 0.0 & 23.1 & 62.5 & 0.0 & \\
\hline & \multirow{2}{*}{ Very rarely } & $\mathrm{N}$ & 3 & 9 & 0 & 0 & \\
\hline & & [\%] & 100.0 & 69.2 & 0.0 & 0.0 & \\
\hline \multirow{2}{*}{\multicolumn{2}{|c|}{ Total }} & $\mathrm{N}$ & 3 & 13 & 8 & 1 & \\
\hline & & [\%] & 100.0 & 100.0 & 100.0 & 100.0 & \\
\hline
\end{tabular}

$\mathrm{p}$ - significance; $\times 2$-test statistic; $\mathrm{df}$ - degrees of freedom

Table 23. Support from breast cancer support group

\begin{tabular}{ccc}
\hline & N & [\%] \\
\hline Yes, I received support & 25 & 100.0 \\
\hline
\end{tabular}

Table 24. Participation in breast cancer support group meetings and improvements in the quality of life.

\begin{tabular}{ccc}
\hline & N & [\%] \\
\hline Yes, it improved my quality of life & 25 & 100.0 \\
\hline
\end{tabular}

Many study patients had considerable difficulty carrying groceries (44\%); $40 \%$ of the women assessed in the study had slight difficulty with this task (Table 14)

Most study patients admitted that they had slight difficulty during sleep (64\%); eight patients (32\%) had fairly considerable difficulty.

The majority of study patients admitted that they had slight difficulty with personal hygiene activities (64\%); nine women had fairly considerable difficulty with this task.

Most study patients had considerable (52\%) or fairly considerable (28\%) difficulty doing sports.

Most study patients had either fairly considerable (28\%) or considerable (28\%) difficulty cleaning the house (Table 15)

The majority of study patients participated in meetings with a psychologist (72\%) (Table 16$)$.

Most patients believed that the psychologist helped them accept their new life situation (56\%). Unfortunately, four women (16\%) were unable to accept their changed life situation.

$20 \%$ of study patients experienced sadness, grief, and low mood (Table 17)

Most study patients either fully accepted (36\%) or partly accepted (36\%) their physical appearance. Four study patients (16\%) said they had managed to get used to it (Table 18).

All study patients confirmed that during treatment, they had the full support of their loved ones and that their relationship with family members did not deteriorate during treatment.

Most study patients found out they could join a breast cancer support group on the Internet (40\%) or from their acquaintances (28\%) or healthcare professionals (24\%).

All study patients found support in the breast cancer support group.
All study patients responded that taking part in meetings of the breast cancer support group improved their quality of life (Table 19).

\section{RESULTS}

Hypothesis: Upper limb pain occurred more often in women who had a limited range of motion after surgery.

An analysis was performed to check for the presence of a statistically significant correlation between two variables (Do you experience pain in your arm on the operated side? and Do you have a limited range of motion in your arm on the operated side after surgery?). Fisher's test for $\mathrm{R} \times \mathrm{C}$ tables was used. There is a correlation between the variables (Table 20).

Pain was definitely most common in patients with a limited range of motion; as many as $85.7 \%$ of these patients experienced pain. In the other patients, the incidence of pain was up to $12.5 \%$.

Study patients usually accepted their physical appearance (36\%) (Table 21)

The $\mathrm{p}$ value was lower than 0.05 , which means that there was a relationship between the variables. All women who rated their current health as poor often experienced negative emotions (Table 22).

Hypothesis: Most women found support and understanding in a breast cancer support group and believe that their participation in group meetings improved their quality of life.

All study patients found support in the breast cancer support group and believed that the group improved their quality of life (Table 23-24).

\section{DISCUSSION}

The aim of the present study was to assess the quality of life in women after mastectomy and to determine the influence of rehabilitation on their quality of life.

The study included a total of 25 women who were members of the breast cancer support group (Amazon Club) at the Holy Cross Cancer Centre in Kielce. Most study patients described their health as good (52\%). Nevertheless, when asked about their quality of life, many patients 
admitted they had difficulty bathing, dressing, carrying heavy objects, shopping, cleaning, brushing their hair, and cooking; eating meals was the least difficult activity.

Breast reconstruction after its removal is one of the methods of improving the quality of life in women after mastectomy. The majority of study patients who underwent breast reconstruction believed that the procedure had a significant positive influence on their everyday life.

Breast prostheses are used as an alternative to breast reconstruction and serve a similar purpose. Only half of the study group (48\%) felt good wearing a breast prosthesis and used and accepted it. Four study patients (16\%) wore a breast prosthesis out of necessity, but were unable to accept it. The other patients did not use breast prostheses. The majority of women who wore and accepted a breast prosthesis believed that the prosthesis improved their quality of life.

Rehabilitation is as important as breast reconstruction and prostheses. The majority of the women assessed in the study (96\%) underwent rehabilitation with a physiotherapist after mastectomy and most patients described their therapy as either very good (56\%) or good (28\%). In addition, study patients believed that rehabilitation had a positive influence on their quality of life and everyday functioning (92\%).

Physical activity is very important in the process of rehabilitation. More than half of the study group admitted that they had considerable $(52 \%)$ or fairly considerable $(28 \%)$ difficulty doing sports and engaging in physical activity. Consequently, it would be beneficial to create conditions that would allow women after mastectomy to take up physical activity and promote the positive influence of physical activity on the motor function in the upper limb on the side of surgery.

Psychologists play a very important role in breast cancer treatment as they help patients accept and understand their disease and find motivation to continue fighting it. The majority of study patients met with a psychologist (72\%) and believed that the psychologist helped them accept their new life situation.

The study showed that all women who rated their health as poor often experienced negative emotions.

The study formulated a hypothesis that most women found support and understanding in their breast cancer support group and believed that their participation in group meetings improved their quality of life. All study patients found support in the breast cancer support group and believed that the group improved their quality of life.

A study conducted by Jankau et al. [14] showed that mastectomy has a negative effect on the general condition and quality of life in women. The quality of life is the best when it comes to the physical aspects and the worst when it comes to mental wellbeing. Age and physical activity also have an influence on the quality of life. Breast reconstruction surgery and breast prostheses improve the quality of life in women after mastectomy.

According to a study by Szczepańska-Gieracha et al. [19], breast cancer has a negative influence on patients' emotional state, causes an increase in anxiety levels, and contributes to negative emotions.
A study by Zegarski $W$ et al. [20] revealed that the quality of life in breast cancer patients deteriorates during chemotherapy and patients experience sadness, anxiety, fear, and physical symptoms such as nausea, vomiting, and pain. Nevertheless, support from loved ones helps most patients cope with their cancer. Women receive significant help from breast cancer support groups.

\section{CONCLUSIONS}

1. Mastectomy affects ipsilateral upper limb function and causes difficulty with activities of daily living, such as cleaning, cooking, brushing hair, bathing, and dressing.

2. All women who rated their health as poor experienced such negative emotions as sadness, low mood, dejection.

3. Breast reconstruction after mastectomy improved patient-rated quality of life.

4. All women who participated in breast cancer support group meetings found support there and the time they spent together resulted in an improved quality of life.

\section{REFERENCES}

1. Manghan KL, Lutterbie MA, Ham PS. Treatment of breast cancer. Am Fam Physician. 2010;81(11):1339-46.

2. Merino Bonilla JA, Torres Tabanera M, Ros Mendoza LH. Brest cancer in the 21st century: from early detection to new therapies. Radiologia 2017;59(5):368-379.

3. Anastasiadi $Z$, Lianos GD, Ignatiadou $E$ et al. Brest cancer in young woman: an overview updates surg. 2017;69(3):313-317.

4. Fahad Ullah M. Brest cancer: Perspectives on the disease status. Adv Exp Med Biol. 2019;1152:51-64.

5. Desantis C, Siegel R, Bandi P, Jemal A. Brest cancer statistic, 2011 CA. Cancer J Clin. 2011;61(6):409-18.

6. Matsen $C B$, Neumayer LA. Brest cancer: a review for the general surgeon. JAMA Surg. 2013;148(10):971-9.

7. Dauplat J, Kwiatkowski F, Rouanet $P$ et al. Quality of life after mastectomy with or without immediate breast reconstruction. $\mathrm{Br} J$ Surg. 2017;1049(9):1197-1206.

8. Browne JP, Jeevan R, Gulliver-Clarke C et al. The association between complications and quality of life after mastectomy and breast reconstruction for breast cancer. Cancer. 2017;123(18):3460-3467.

9. Lederc AF, Foidart-Dessalle $M$, Tomasella $M$ et al. Multidisciplinary rehabilitation program after breast cancer: benefits on physical function, antropometry and quality of life. EurJ J Phys Rehab Med. 2017;53(5):633-642.

10. Aygin $D$, Cengiz $H$. Life quality of patients who underwent breast reconstruction after prophylactic mastectomy: systematic review. Brest Cancer. 2018;25(5);497-505.

11. Velikova G, Williams $L J$, Willis $S$ et al. Quality of life after postmastectomy radiotherapy in patients with intermedicate-risk breast cancer (SUPREM0); 2-year follow-up results of a randomized controlled trial. Lancet Oncol. 2018;19(11):1516-1529.

12. Salibasic M, Delibegovic $S$. The quality of life and degree of depression of patients suffering from breast cancer. Med Arch. 2018;72(3):202-205.

13. Hansdorfer-Korzon R, Burakowska A. Zmiany w obrębie skóry u pacjentek po mastektomii z powodu raka sutka. Forum Med Rodz. 2010;4(3):174-178.

14. Jankau J,Trus-Urbańska M, Renkielska A.Zmiana jakościżycia po zabiegu rekonstrukcji piersi. Forum Med Rodz. 20115(5):414-419. 
15. Kalinowski P, Krawulska A. Rola fizjoterapii po mastektomii w opinii pacjentek. Med Ogol Nauk Zdr. 2012;18(4):291-292

16. Kulpa M, Owczarek K, Stypuła-Ciuba B. Przystosowanie psychiczne do choroby nowotworowej a jakość życia uwarunkowana stanem zdrowia u chorych onkologicznych. Med Paliat. 2013;5(3):106-113

17. Mniszewska J, Chodkiewicz J, Zalewska-Jankowska A. Jakość życia w zdrowiu i chorobie - czym jest, jak i po co ją oceniać. Prz Lek. 2012;69:253-258.

18. PawlikM, Kaczmarek-Borowska B. Akceptacja choroby nowotworoweju kobiet po mastektomii. Prz Med Uniw Rzesz Inst Lekow. 2013;2:204-205.

19. Szczepańska-GierachaJ,Malickal,FigułaM,RymaszewskaJ,WoźniewskiM. Wpływ ośmiotygodniowego treningu nordic walking na jakość życia kobiet po mastektomii. Onkol Pol 2010;13:90-95.

20. Zegarski W, Głowacka I, Ostrowska Ż. Ocena jakości życia kobiet po mastektomii na podstawie standardowych kwestionariuszy: QLQ-C30 i QLQ-BR23. Nowotwory. 2010;60(6):532-532.

\section{ORCID and contributionship:}

Włodzisław Kuliński - 0000-0002-6419-4030 A, B, D, E, F

Michat Kosno ${ }^{\text {B, } C, D, E}$

\section{Conflict of interest:}

The Authors declare no conflict of interest.

\section{CORRESPONDING AUTHOR Włodzisław Kuliński \\ ul. K Miarki 11B \\ 01-496 Warszawa, Poland \\ e-mail wkulinski52@hotmail.com}

Received: 12.01 .2021

Accepted: 22.02.2021

A - Work concept and design, B - Data collection and analysis, C - Responsibility for statistical analysis,

D-Writing the article, $\mathbf{E}$-Critical review, $\mathbf{F}-$ Final approval of the article 